\title{
REPRESENTASI KRITIK MELALUI HUMOR DALAM MEDIA DIGITAL YOUTUBE DI CHANEL MAJELIS LUCU INDONESIA
}

\author{
Fronqi Bella Enrin 1 ) \\ 1)UIN Sayyid Ali Rahmatullah Tulungagung \\ 1)fronqibella@gmail.com
}

\begin{abstract}
Abstrak. Kebebasan berekspresi adalah hak individu untuk membagi dan menerima informasi, memperbincangkan hal tersebut, dan menyebarkannya. Kebebasan berekspresi sering kali disamakan dengan kebebasan pers, sebenarnya hal ini berbeda di lihat kebebasan berekspresi diartikan sangat luas sementara kebebasan pers hanya di fokuskan pada penyiaran, media cetak,jurnalis, dan jurnalisme. Kebebasan berekspresi dapat menjadi sarana komunikasi melalui banyak media salah satunya adalah sosial media youtube. Kebebasan berekspresi melalui media sosial youtube memiliki aturan dan dampak tersendiri mengingat pengguna media sosial youtube terbagi dari banyak lapisan usia. Penelitian ini menggunakan referensi jurnal-jurnal penelitian serupa sebelumnya dan buku sebagai sumber data.
\end{abstract}

\section{Kata Kunci: kebebasan berekspresi, komunikasi, youtube}

\begin{abstract}
Freedom of expression is the right of individuals to sharing and receive information, discuss it and pass it on. Freedom of expression is often equated with freedom of the press, in fact this is different in that freedom of expression is interpreted very broadly while press freedom is only focused on broadcasting, print media, journalists, and journalism. Freedom of expression can be a means of communication through many media, one of which is the social media youtube. Freedom of expression through the social media youtube has its own rules and impacts considering that YouTube social media users are divided from many age groups. This study uses references to previous similar research journals and books as data sources.
\end{abstract}

Keyword : freedom of exspression, communication, youtube

\section{PENDAHULUAN}

Kebebasan berekspresi adalah bagian dari hak asasi manusia yang terkandung didalamnya sebagai bagian penting dan tidak terpisahkan dari bagian pemerintahan dan nilainilai demokrasi. Terdapat hubungan langsung diantara kebebasan berpikir dan kebebasan berekspresi, yang merupakan suatu yang penting bagi individu untuk memandu pemikiran dan konsepnya. Setiap orang memiliki kesempatan untuk mengungkapkan pemikiran dan idenya di depan umum, ini adalah bentuk realisasi diri yang spesifik, yang memungkinkan mereka menjadi anggota masyarakat yang resmi dan mengekspresikan diri dengan bebas, ini adalah karakteristik masyarakat yang demokratis.

Sejarah kebebasan berekspresi modern dapat dilihat pada abad ke-14, ketika Eropa mulai mengembangkan teknologi pencetakan. Kemudian, "Amandemen Pertama Konstitusi 
AS" pada abad kedelapan belas memberi dunia perlindungan pertama atas hak kebebasan berbicara. Perjuangan berikutnya setelah "Amandemen Pertama" adalah sulitnya mendefinisikan makna kebebasan berekspresi yang berujung pada berbagai masalah. Terdapat 3 tema utama dalam setiap debat tentang kebebasan berbicara adalah pertama pemerintah membatasi kritik atau publik, kedua pemerintah memiliki hak menyensor publikasi berita, dan pemerintah memiliki hak untuk melarang ekspresi pemikiran atau pidato. Informasi yang dianggap berdampak negatif bagi publik.

Salah satu bagian yang penting dalam demokrasi ialah kebebasan berekpresi bahkan pada tahun 1946 majelis umum PP menyatakan "Hak atas informasi merupakan hak asasi manusia fundamental dan standar dari semua kebebasan yang dinyatakan 'suci' oleh PBB" pada resolusi nomor 59 sebelum disahkannya Universal Declaration on Human Rights. Partisipasi dan kebebasan berekspresi merupakan salah satu syarat penting yang mempengaruhi keberlangsungan demokrasi. John Locke mengemukakan kebebasan berekspresi ialah cara untuk mendapatkan kebenaran. Hal ini juga diartikan sebagai kebebasan dapat mencari, menyebarluaskan dan mendapatkan informasi serta membicarakannya entah membantu ataupun mengkritiknya. John Stuart Mill mengungkapkan kebebasan berekspresi dibutuhkan untuk melindungi warga dari penguasa yang korupsi dan tiran. ${ }^{1}$ Kebebasan berekspresi dengan demokrasi kemudian diakui dalam hukum internasioanl hak asasi manusia yang menyatakan bahwa kebebasan berekspresi merupakan pra-syarat terwujudnya transparansi dan akuntabilitas yang sangat penting bagi kemajuan dan perlindungan hak asasi manusia. Kebebasan berekspresi ialah salah satu sarana guna mencari pilihan yang paling rasional serta membangun rasionalitas di dunia yang modern ini.

Kebebasan berekspresi juga sering dikenal sebagai kebebasan berbicara dan sering dikaitkan dengan kebebasan pers. Kebebasan ekspresi mencakup cara lisan, tercetak, audiovisual, budaya, artistic, dan juga politik. Sedangkan kebebasan pers lebih ditujukan ke media penyiaran, jurnalisme dan jurnalis. Kebebasan berekspresi cenderung memungkinkan masyarakat untuk mencapai kestabilan dan beradaptasi didalam masyrakat. Kebijakan penyiaran pada dasarnya adalah hasil dari interaksi antara kepentingan industry, negara dan masyarakat yang terus mengalami perubahan sesuai dengan perkembangan zaman.

1 Rahmanto, Tony Yuri, KEBEBASAN BEREKPSRESI DALAM PERSPEKTIF HAK ASASI MANUSIA: PERLINDUNGAN,PERMASALAHAN DAN IMPLEMENTASINYA DI PROVINSI JAWA BARAT. (badan penelitian dan pengembangan hukum dan HAM kementerian hukum dan HAM RI, 2016) 
Suatu cara bagaimana peristiwa disajikan oleh media disebut sebagai framing. Framing dilakukan dengan menonjolkan bagian tertentu dari suatu aspek dan membesarkan hal tersebut dari realitas. Robert N. Entman menganalisis salah satu pendekatan analisis framing yang menganalisa teks media. Robert N. Entman mengemukakan mengenai apa yang kita ketahui tentang realitas adalah tergantung pada bagaimana kita membingkai realitas tersebut.

Framing ialah metode penyajian berita dengan menyusun realitas sesuai dengan ideide media. Setiap hasil laporan adalah hasil konstruksi realistis dari insiden yang dilaporkan. Konsep framing telah digunakan secara luas dalam literature ilmu komunikasi untuk menggambarkan proses penseleksian dan penyorotan aspek-aspek khusus sebuah berita oleh media. Dalam bidang penelitian komunikasi, analisis bingkai merepresentasikan tradisi dan mengusulkan pendekatan atau sudut pandang multidisiplin untuk menganalisis fenomena atau aktivitas komunikasi. Saat menyusun fakta, gunakan analisis bingkai untuk menganalisis media atau ideologi. Analisis tersebut mengkaji strategi pemilihan, keunggulan dan menghubungkan fakta dengan berita agar lebih bermakna, menarik, bermakna atau berkesan, untuk menemani interpretasi audiens berdasarkan sudut pandang audiens. ${ }^{2}$

Framing terbagi menjadi dua bagian besar yaitu seleksi isu dan penekanan bagianbagian tertentu dari realitas. Tujuan framing adalah menonjolkan suatu isu dengan mengabaikan isu yang lain. Wartawan menggunakan cara pandang pendekatan framing dalam menulis berita. Seleksi isu berkaitan dengan pemilihan realitas untuk ditampilkan dengan proses memasukan dan mengeluarkan berita dengan memilih bagian dari isu yang ingin ditampilkan, penyampaian realitas dari isu yang telah dipilih sebelumnya. Framing menentukan bagaimana menghadirkan realitas kepada khalayak. Strategi bagaimana realitas atau dunia dibentuk dan disederhanakan sedemikian rupa untuk ditampilkan kepada khalayak. Acara ditampilkan dalam berita agar menonjol dan menarik perhatian pembaca. Itu dilakukan dengan memilih, mengulangi, menekankan dan menghadirkan aspek-aspek tertentu dari realitas. Pemahaman kita tentang realitas atau dunia bergantung pada bagaimana kita membingkai dan membangun / menafsirkan realitas. Ketika realitas terstruktur atau dikonstruksi dengan cara yang berbeda, realitas yang sama dapat menghasilkan realitas yang berbeda. ${ }^{3}$

Media baru adalah salah satu bentuk penghitungan media yang mengandalkan komputer untuk redistribusi. Beberapa contoh media baru termasuk animasi komputer,

2 Alex Sobur, analisis teks media: suatu pengantar untuk analisis wacana, analisis semiotik dan analisis framing (Remaja Rosdakarya, 2001).

3 Eriyanto, "ANALISIS FRAMING Konstruksi, Ideologi, dan Politik Media” (LKIS PELANGI AKSARA, 2002). 
permainan komputer, antarmuka manusia-mesin, instalasi komputer interaktif, situs web, dan dunia maya. Media baru sering dikontraskan dengan "media lama" seperti televisi, radio, dan media cetak, meskipun para sarjana komunikasi dan studi media mengkritik perbedaan kaku berdasarkan kebaruan dan kebaruan. Media baru bukan termasuk program televisi siaran analog, film feature, buku ataupun majalah kecuali mengandung teknologi yang mendukung pembuatan digital atau proses interaktif. Wikipedia (ensiklopedia online) adalah contoh media baru yang menghubungkan teks digital, gambar dan video yang dapat diakses internet dengan tautan web, partisipasi kreatif oleh kontributor, umpan balik pengguna interaktif, dan editor dan donor yang berpartisipasi dalam acara gabungan pembentukan komunitas dan minat pembaca non-komunitas. Media sosial atau layanan jejaring sosial, seperti tweter dan facebook, adalah contoh tambahan dari media baru yang sebagian besar penggunanya juga merupakan pesertanya.

Youtube telah dikritik karena operasinya, termasuk menangani konten berhak cipta yang terdapat dalam video yang diupload, algoritme rekomendasinya menangkap video yang mempromosikan teori dan kebohongan konspirasi, dan hosting yang tampaknya menargetkan anak-anak tetapi berisi kekerasan atau isyarat seksual yang melibatkan karakter populer. Video konten, video dari anak di bawah umur menarik aktivitas pedofilia di bagian komentar mereka, dan kebijakan volatilitas terkait jenis konten yang dapat dimonetisasi melalui iklan.

Channel youtube Majelis Lucu Indonesia (MLI) adalah sebuah channel yang diciptakan dari berbagai komedian "Stand Up Comedy" yang ada di Indonesia seperti Dono Padana, Tretan Muslim, Coki pardede dan masih banyak lagi. Dalam channel ini para komedian membuat banyak konten didalamnya seperti Roasting, wawancara, investigasi dsb. Kebanyakan dichannel MLI memiliki konten yang menyampaikan pendapat mereka sesuai dengan pemikiran komedian tersebut, bahkan pendapat mereka kadang memicu banyak persoalan atau masalah dari penonton.

Salah satu konten di MLI yang banyak mengutarakan pendapat mereka yaitu pada konten berjudul "Pengen Siaran" yang dibawakan oleh komedian Tretan Muslim dan Coki Pardede. Konten ini mengandung banyak pendapat yang dapat menimbulkan pro dan kontra dari mereka berdua atau pendapat dari orang lain seperti bintang tamu yang disampaikan kepada khalayak umum secara komedi. Jumlah subscribers dari channel MLI sudah mencapailebih dari satu juta akun dan jumlah penonton dari tiap tayang rata rata mencapailebih dari dua ratus ribu penonton. Hal ini menandakan bahwa channel ini semakin banyak diminati oleh banyak penonton. Selain itu faktor publik figur disini juga berpengaruh 
terhadap channel ini karena channel ini diisi oleh komedian yang sudah terkenal di berbagai ajang kompetisi stand up comedy bahkan di channel ini juga ada Joshua Suherman yang dulu dikenal sebagai penyanyi cilik yang terkenal pada jaman dahulu, dan sekarang ia menjadi aktor film dan juga sebagai salah satu stand up komedian di MLI.

Penelitian mengenai kebebasan berekspresi banyak ditemui diberbagai jurnal dan ada juga buku mengenai kebebasan berekspresi dengan berbagai versi yang ada adapun kesamaan penelitian ini dengan penelitian yang lainnya seperti "Kebebasan Berekspresi dalam Prespektif Hak Asasi Manusia: Perlindungan, Permasalahan dan Implementasinya di Provinsi Jawa Barat" di tulis oleh Tony Rahmanto pada tahun 2016, “Ancaman kebebasan Berekspresi di Media Sosial" ditulis oleh Mufti Nurlatifah, S. IP. M. A. Pada tahun 2016. "Motif dan Kebebasan Berekspresi dalam Meme" ditulis oleh Ahmad Kamal Abdul Jabbar pada tahun 2019. "Representasi Kritik Sosial dalam Tayangan Stand Up Comedy Indonesia Kompas TV" ditulis oleh Burhanuddin pada tahun 2015. Perbedaan penelitian ini dengan penelitian terdahulu seperti yang disebutkan diatas terdapat pada objek penilitian serta metode yang digunakan dan juga penelitian ini menyangkut kebebasan berekspresi secara humor yang digunakan sebagai kritik melalui media youtube. Dari pendahuluan diatas peneliti merumuskan permasalan sebagai berikut, bagaimanakah kebebasan berekspresi secara humor diterapkan melalui media digital youtube?

\section{METODE}

Mengumpulkan data merupakan sesuatu yang penting untuk proses penelitian, teknik pengumpulan data yang benar akan menghasilkan penelitian yang benar akan menghasilkan data yang memiliki kredibilitas tinggi, jika terdapat kesalahan atau tidak sesuai dengan prosedur yang benar maka akan berakibat buruk yakni data tidak credible. Didalam metode penelitian kualitatif yang dimaksud data adalah segala informasi baik lisan maupun tulis bahkan foto ataupun gambar yang bersangkutan untuk menjawab masalah penelitian seperti pada penelitian ini kami membahas kebebasan berekspresi melalui media digital youtube.

Pada penelitian ini penulis menggunakan teknik pengumpulan data Observasi yang dimana metode ini ialah teknik pengumpulan data yang yang menghasilkan aktivitas, kejadian, peristiwa, objek, kondisi atau suasana tertentu dan perasaan emosi seseorang. Observasi dilakukan untuk memperoleh gambaran nyata suatu peristiwa atau kejadian untuk menjawab pernyataan penelitian. Dengan melihat fenomena atau peristiwa tentang kebebasan 
berekspresi yang ada di Indonesia melalui situs berbagi video youtube peneliti akan meneliti bagaimana kebebasan berekspresi itu bisa berjalan dengan baik atau tidak.

Selain metode Observasi saya juga menggunakan metode Dokumentasi yang mana informasi juga bisa diperoleh lewat fakta yang tersimpan dalam catatan harian, arsip foto, jurnal kegiatan, hasil rapat, dan sebagainya. Data berupa dokumen tersebut dapat digunakan untuk menggali informasi yang telah terjadi di masa lalu. Peneliti akan mendapatkan data dari peraturan mengenai kebebasan berekspresi yang ada di Indonesia seperti undang-undang yang mengatur kebebasan berekspresi serta mengetahui sejarah komedi melalui jurnal-jurnal yang ada.

Penelitian ini akan membahas mengenai kebebasan berekspresi yang disampaikan secara humor yang dimana kebebasan berekspresi di Indonesia sendiri dibayangi dengan peraturan yang ada seperti UU ITE. Komunikasi secara humor adalah bentuk dari kebebasan berekspresi dalam penyampaian pesan untuk tujuan tertentu seperti untuk menghibur atau bentuk argumen yang dikemas secara komedi. Jenis Penelitian ini menggunakan metodologi penelitian kualitatif dengan pendekatan analisis framing model Robert $\mathrm{N}$ Entmen dan berdasarkan teori semiotika Ferdinand de Saussure.

Menurut Ferdinand de Saussure, tanda terdiri dari 2 aspek yaitu:

1. Bunyi-bunyi dan gambar (Sounds and Images) yang disebut signifier.

2. Konsep-konsep dari bunyi dan gambar (The concepts these sounds and images) yang disebut "signified" berasal dari kesepakatan.

Tanda ialah sesuatu yang berbentuk fisik (any sound-image) yang dapat di lihat dan didengar yang biasanya mengacu kepada sebuah objek atau aspek dari kenyataan yang ingin dikomunikasikan. Objek tersebut dikenal dengan "referent". Dalam berkomunikasi, seseorang yang menggunakan tanda untuk mengirim suatu makna tentang sebuah objek dan orang lain akan menafsirkan tanda tersebut. Syaratnya ialah penyampai pesan dan penerima pesan harus mempunyai bahasa atau pengetahuan yang sama terhadap sistem tanda. ${ }^{4}$

Inti dari teori Saussure ialah prinsip yang mengatakan bahwa bahasa adalah suatu sistem tanda dan tanda terdiri dari dua bagian, yaitu signifier (penanda) dan signified (petanda). Penanda dapat diartikan sebagai sebuah ide atau sesuatu yang bermakna. Penanda adalah aspek material dari bahasa, yaitu apa yang dikatakan atau didengar dan apa yang ditulis

${ }^{4}$ Maldo, M, Representasi Nilai Islam pada Iklan BNI Syariah" Hasanah Titik!" Studi Analisis Semiotika Ferdinand De Saussure (Doctoral dissertation, Universitas Islam Riau. 2017). 
atau dibaca. Sedangkan petanda adalah suatu gambaran mental, konsep, atau pikiran. Jadi, petanda adalah bagian mental dari bahasa.

\section{PEMBAHASAN}

1. Penanda dan petanda

Dalam penelitian ini Majelis Lucu Indonesia menjadi subjek utama dengan materi konten "Pengen siaran" dengan video berjudul " Himbauan Untuk Adik-Adik yang Sedang Ospek" subjek akan diteliti dengan pendekatan framing dengan analisis Robert N. Entman yang menampilkan dua dimensi dalam framing yaitu penonjolan dan seleksi isu.

Konten "Pengen Siaran" dengan video berjudul "Himbauan untuk Adik-Adik yang Sedang Ospek" dibawakan oleh Tretan Muslim dan Coki Pardede dalam media sosial youtube pada 8 bulan lalu di channel youtube Majelis Lucu. Keseluruhan isu yang diangkat pada konten "Pengen Siaran" dalam video yang berjudul "Himbauan untuk Adik-Adik yang Sedang Ospek" membahas mengenai budaya Ospek yang saat ini dijalankan secara daring yang dibalut dengan komedi. Isu ini diangkat dari fenomena viral pada tahun 2020 dimana ada video yang beredar mengenai ospek yang dijalani di suatu universitas yang menunjukan senioritas dan perilaku kasar secara verbal pada mahasiswa baru.

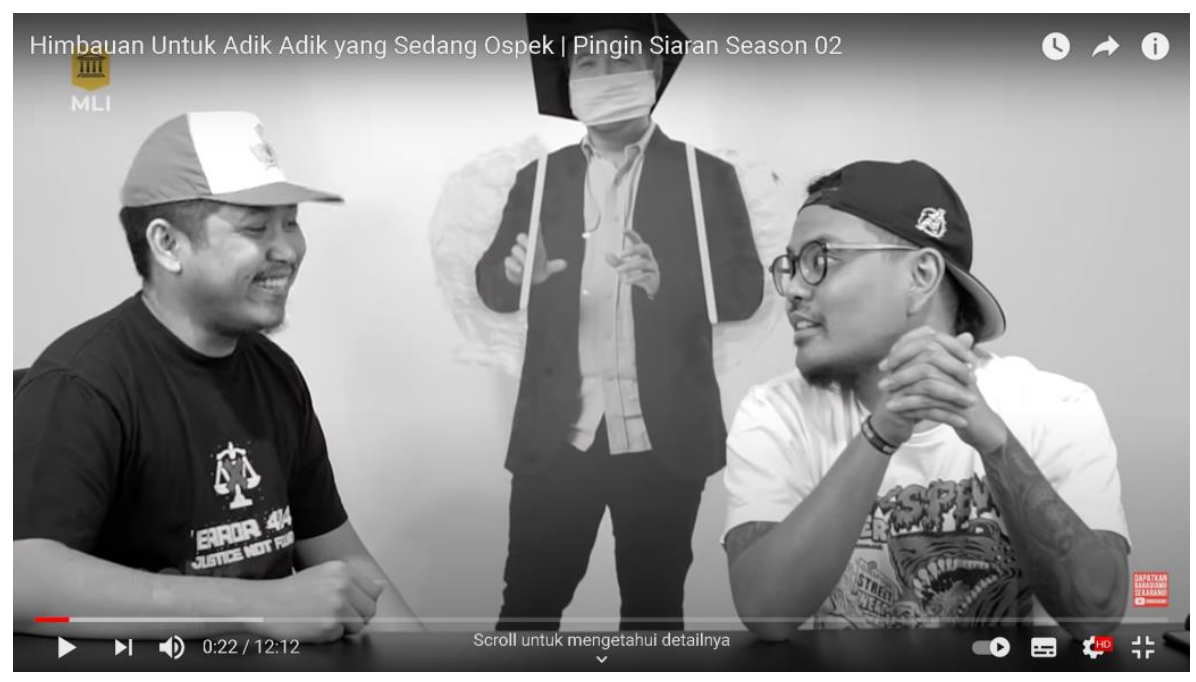

Di awal video yang dibuka oleh 2 pembawa acara yang merupakan komedian dari kompetisi Stand Up Comedy di salah satu TV Nasional yaitu, Tretan Muslim dan Coki Pardede. Tretan Muslim yang mengenakan topi siswa SMA yang merupakan sebagai "penanda", memulai acara dengan gestur menyindir para senior di setiap kampus yang budayanya tidak pernah hilang yaitu membentak para juniornya/mahasiswa baru dengan menggrebak meja dan mengatakan tema dari video ini yaitu ospek sebagai "petanda". Namun, rekan dari Tretan 
Muslim, yaitu Coki Pardede memberikan statement bahwa senioritas dalam pelaksanaan ospek di setiap kampus sudah tidak ada karena terhalang oleh Pandemi sehingga Ospek dilaksanakan secara Online melalui aplikasi media pembelajaran online. Lantas, Tretan Muslim memberitahu kepada Coki Pardede, bahwa memang senioritas dengan kekerasan secara fisik sudah tidak ada karena hal tersebut dilakukan hanya ketika ospek tersebut dilaksanakan secara tatap mata dan muka. Namun saat ini, di kondisi Pandemi dan Ospek Online, kegiatan ospek yang meyimpang tersebut diganti dengan kekerasan secara verbal dengan membentak para Junior atau mahasiswa baru seperti yang dilakukan oleh beberapa mahasiswa di salah satu Universitas di Surabaya, Jawa Timur yang membuat banyak tanggapan pro dan kontra bermunculan. Coki Pardede pun sempat kaget karena tidak update dan mengikut masalah video viral ospek online tersebut, dan menanyakan apa sesungguhnya fungsi dari membentak dan kekerasan verbal secara online yang dilakukan dalam pelaksanaan kegiatan Ospek online mahasiswa baru tersebut.

Kedua comedian ini pun menunjukkan kebebasan berekspresi secara humor dengan mempraktikkan apa yang ada dalam video sebagai "penanda" tersebut dengan jokes - jokes yang mereka miliki sebagai "petanda". Sebagai comedian mereka juga menyampaikan pesan dengan baik dengan balutan humor di awal video tersebut sehingga penonton dapat mengambil pesan dari mereka, bahwasannya jika kita diposisikan sebagai junior/mahasiswa baru dan dibentak secara online, kita tidak perlu takut kepada mereka karena kita bisa mengecilkan volume dan tidak mendengar apa yang senior katakan karena memang itu tidak sepantasnya dikatakan untuk menghindari rasa trauma ataupun takut kedepannya karena ospek online tersebut. Selanjutnya, Tretan Muslim menceritakan mulai dari jaman dia sekolah hingga sekarang ini, budaya kita di negara Indonesia tentang senioritas dalam kegiatan ospek khususnya, tidak bisa dihilangkan bahwa senior selalu ingin memberikan efek jera dari apa yang diterimanya dari senior sebelumnya atau bisa dibilang sebagai rasa balas dendam dan Tretan Muslim pun menyampaikan bahwa harapannya dengan pandemi ini, budaya senioritas dengan kekerasan dapat terhenti. Selain membentak, ternyata di kampus lain dalam pelaksanaan ospek nya juga mengalami penyimpangan dimana para senior memberikan perintah kepada mahasiswa untuk mencoret - coret muka mereka dengan lipstick hingga menutupi semua muka mereka hingga mereka merasa malu di depan teman - temannya. Lantas, kedua comedian ini baik Coki Pardede dan Tretan Muslim bertanya - tanya dan menunjukkan kebebasan berekspresi mereka dengan secara humor, mengapa hal itu dituruti oleh para Junior mereka? Apa yang harus ditakutkan dari ospek online ketika kita tahu 
perbuatan tersebut tidak termasuk dalam kegiatan ospek, maka juga tidak perlu dituruti atau bisa juga dengan alasan sinyal dan jaringan yang tidak stabil.

Kedua comedian ini melanjutkan kebebasan berekspresi mereka secara humor dengan mempraktikkan bahwa jika yang menyuruh adalah dosen, ataupun petinggi - petinggi di kampus wajar jika junior atau mahaiswa baru harus takut dan melakukannya karena akan berpengaruh di akademik mereka. Tretan dan Coki juga menambahkan dengan membuat pengandaian jika dalam kegiatan ospek tersebut sosok yang memberikan perintah kepada para mahasiswa baru tersebut adalah sosok terpandang dan terhormat seperti Ibu Walikota Surabaya atau yang sekarang menjadi Mentri Sosial Indonesia yaitu Ibu Risma.

Dalam scene berikutnya, kebebasan berekspresi secara humor ditunjukkan oleh Tretan Muslim dengan memberikan pesan kepada para senior yang masih melakukan penyimpangan dalam melaksanakan kegiatan ospek kepada para juniornya. Tretan muslim menyampaikan pesan nya dengan humornya bahwa untuk melatih mental para junior dan mahasiswa baru di setiap kampus, seharusnya dengan menyuruh mereka memasak babi dengan rasa kurma, yang akan benar - benar melatih mental, psikis, jantung, maupun financial karena akan membingungkan mereka makanan tersebut halal atau haram dan resep apa yang pas untuk memasak menu tersebut. Tentu melalui jokes yang disebutkan oleh Tretan Muslim tersebut, penonton akan mengetahui bahwa hal tersebut merupakan jokes untuk menyampaikan pesan kepada para senior dengan kebebabasan berekspresi secara humor karena background acara mereka adalah comedian.

Karena salah satu video senioritas dalam pelaksanaan ospek online yang menggunakan kekerasan secara verbal tersebut viral di media sosial, pihak - pihak yang terlibat dalam penyimpangan kegiatan ospek tersebut menyelesaikan masalah secara kekeluargaan. Bersama pihak kampus, para senior mendatangi rumah mahasiswi baru yang tampak dalam video ospek tersebut untuk meminta maaf secara langsung dan menyesali perbuatan mereka tersebut. Namun, Coki Pardede menanyakan jika ingin melatih mental, mengapa harus diselesaikan secara kekeluargaan tidak diselesaikan di persidangan agar mental dari para senior juga diuji disana. 


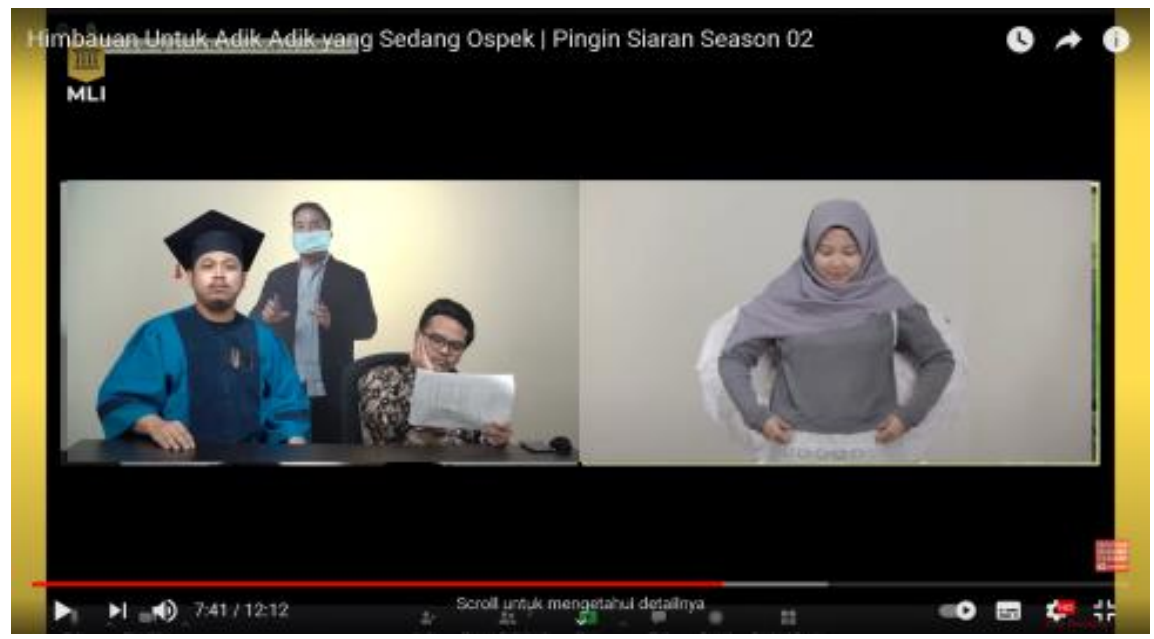

Menariknya, di akhir video Tretan Muslim, Coki Pardede dan salah satu teman mereka melakukan reka adegan video ospek yang viral tersebut. Tretan Muslim sebagai senior, Coki Pardede sebagai dosen ataupun petinggi kampus, dan rekan mereka sebagai junior ataupun mahasiswa baru merupakan sebagai "penanda". Dalam reka adegan tersebut, mereka juga melakukan kebebasan berekespresi secara humor dengan menganggap bahwa ospek tujuannya adalah membuat para mahasiswa baru kerepotan dengan barang bawaan yang langka dan aneh untuk dicari seperti botol pemutih pakaian, kabel roll, dan pukat harimau serta memberikan pertanyaan yang tidak penting dan membentak para mahasiswa baru yang diperagakan dalam reka adegan mereka sehingga membuat para junior merasa jera dan ingin membalaskan dendamnya kepada para junior berikutnya dalam kegiatan ospek di tahun berikutnya. Lucunya, di akhir video Tretan Muslim dan Coki Pardede memberikan argumen bahwasannya yang menyulitkan di tengah pandemi ini tidak hanya senior yang melakukan penyimpangan dalam kegiatan ospek, namun juga pihak kampus yang menyulitkan dengan tidak adanya keringanan biaya Uang Kuliah Tunggal (UKT) di setiap kampus walaupun kuliah dilaksanakan secara online di rumah dan tidak menggunakan fasilitas dari kampus sama sekali yang merupakan sebagai "petanda".

Fakta mengenai ospek adalah kegiatan mengenal kehidupan kampus dan perkuliahan bagi mahasiswa baru. Isu yang dipilih dalam video ini adalah fenomena video ospek yang sempat beredar luas di dunia maya mengenai senioritas dan perilaku kasar secara verbal dari senior pada mahasiswa baru saat masa pengenalan kampus dan kehidupan perkuliahan. Isu yang dihilangkan dari realitas ini adalah kegiatan pengenalan kampus dan kehidupan perkuliahan di universitas lain secara daring dijalankan dengan baik dan diisi dengan webinar dan kegiatan daring untuk mengenal kampus dan dunia perkuliahan secara lebih mendalam. Isu yang di Isu yang ditonjolkan pada video "Himbauan untuk Adik-Adik yang Sedang Ospek" 
adalah perilaku kasar secara verbal yang dilakukan oleh senior pada mahasiswa baru saat kegiatan pengenalan kampus dan dunia perkuliahan yang sempat beredar di dunia maya.

Pada hal ini, Tretan Muslim dan Choki Pardede mempraktikan contoh dari kebebasan berekspresi untuk memperbincangkan suatu isu yang sedang tersebar luas di khalayak dan membagikan opini mereka mengenai hal tersebut melalui platofrm media youtube. Baik dari penanda maupun petanda ditunjukkan dalam video ini dengan baik.

2. Humor Sebagai Kritik

Humor tidak hanya menjadi sarana kritik sosial, tetapi kadang humor juga merupakan sarana penyadaran diri. Di lingkungan di mana beberapa orang yang tidak berdaya membuat kritik langsung, coba lakukan ini dengan menciptakan rasa humor bagi orang-orang yang terlibat. ${ }^{5}$ Di Indonesia siswa suka menggunakan humor sebagai sarana kritik sosial. Hobi ini menunjukkan bahwa siswa adalah orang yang terpelajar, menjadi orang penting, dan harus skeptis agar pikirannya menjadi ilmiah dan tidak hanya menerima segala sesuatu yang ditawarkan. ${ }^{6}$

Fungsi humor yang paling signifikan adalah sebagai alat untuk menekan emosi diri sendiri. Ia percaya bahwa perasaan ini dapat disebabkan oleh berbagai alasan, seperti ketidakadilan sosial, persaingan politik, ekonomi, ras atau kelas, dan pembatasan kebebasan bergerak, gender atau kebebasan berbicara. Ketika ketidakadilan terjadi, biasanya ada humor berupa protes sosial atau pengekangan seksual, yang biasanya menimbulkan humor seksual.

Ketika kritik sosial dalam bentuk tulisan memiliki banyak pro dan kontra, humor sering digunakan untuk membungkus kritik sosial. Kritik sosial dianggap sebagai sarana komunikasi yang dapat mengontrol sistem sosial dalam kehidupan sosial. Wacana Humor Kritik Sosial adalah wacana hiburan yang penciptaannya ditujukan untuk menghibur penonton (meningkatkan rasa tawa) di samping sebagai wahana kritik sosial terhadap segala bentuk ketimpangan yang terjadi di tengah masyarakat. ${ }^{7}$

Humor satir adalah humor yang biasanya digunakan penulis untuk mengkritik dengan mengejek atau mempermalukan seseorang atau sesuatu. ${ }^{8}$ Kritik dalam bentuk humor dalam komik diungkapkan dengan meniru karakter yang mudah dikenali oleh pembaca. Penggunaan bahasa santai dan dialog yang mengundang gelak tawa membuat kritik lebih mudah diterima. Melalui humor yang disajikan oleh Tretan Muslim dan Coki Pradede dapat dikatakan mereka

\footnotetext{
${ }^{5}$ Suhadi, Humor Dalam Kehidupan (Gama Press, 1989).

6 Sujoko, Perilaku Manusia dalam Humor (Karya Pustaka, 1982).

7 Wijana, Dasar-Dasar Pragmatik (Penerbit Andi, 2003)

8 Sugiarto, V. D, Teknik Humor dalam Komedi yang dibintangi oleh stand up comedian (Jurnal EKomunikasi, 2016)
} 
memberikan kritik terhadap berbagai pihak, dengan melalui teori semiotika Ferdinand de Saussure dapat dilihat humor mereka yang dijadikan sebuah kritik terhadap fenomena yang terjadi yang disebutkan di video melalui penanda dan pertanda tersebut.

Penanda pertama dengan Tretan Muslim yang mengenakan "topi” siswa SMA yang merupakan sebagai tanda bahwa acara hari ini bersangkutan dengan siswa SMA. Petanda pertama muncul diawal video dengan kata-kata "ospek" yang menunjukan bahwa tema acara dari video ini adalah ospek yang menyangkut dengan kejadian atau fenemona yang sering diperbincangkan pada saat itu dengan gestur menyindir senior dengan komedi mereka. Melalui petanda ada kritik yang disampaikan muncul dengan melalui kata-kata humor mereka seperti "kenapa adek harus takut dengan senior? Apakah nanti jika kamera digoyang-goyang ditempat adek ikut gempa". Ini menunjukan kritik terhadap siswa-siswa SMA yang mengikuti ospek.

Penanda kedua muncul dengan reka adegan yang dilakukan oleh Coki Pardede sebagai dosen ataupun petinggi kampus, tretan muslim sebagai mahasiswa senior dan satu lagi teman mereka dijadikan sebagai siswa SMA yang melakukan kegiatan ospek dengan menunjukan temannya tersebut didandani konyol sebagai bentuk komedi dan juga kritik terhadap siswa ospek yang selalu didandani aneh" oleh mahasiswa senior mereka. Petanda muncul dengan kritik Tretan Muslim dan Coki Pardede "dipersulit biar mentalnya kuat, oh sama kampus juga mempersulit lagi pendemi biaya kuliah tidak dipotong tetap bayar". Kebebasan berekspresi dengan menggunakan komedi untuk menyampaikan kritik sangat ditonjolkan didalam video ini dengan tujuan menghibur khalayak sekaligus memberikan kritik terhadap pihak-pihak tertentu.

\section{PENUTUP}

Kebebasan berekspresi adalah hak asasi manusia untuk membagi, mendapatkan, memperbincangkan, dan menyebarkan suatu hal. Dalam penelitian ini peneliti ingin menganalisis kebebasan berekspresi dari sebuah konten di sosial media youtube yang ditampilan di channel youtube Majelis Lucu dibawakan oleh Tretan Muslim dan Choki Pardede dengan konten "Pengen Siaran" dalam video berjudul "Himbauan untuk Adik-Adik yang Sedang Ospek" yang ditayangkan 8 bulan lalu.

Analisis framing menurut Robert N. Entman adalah membingkai suatu isu untuk menampakan realitas pada khalayak. Terdapat dua dimensi besar dalam pendekatan framing menurut Robert N. Entman yaitu seleksi isu dimana isu dipilih dari suatu realita dengan 
memasukan atau mengeluarkan isu, lalu penonjolan isu yaitu memfokuskan tampilan pada isu yang dipilih agar menggambarkan realita pada khalayak. Analisis semiotika berdasarkan Ferdinand de Saussure bertujuan untuk mengungkapkan arti petanda dan penanda yang ada dalam suatu karya dan analisis semiotika bisa dilakukan dalam bidang yang lain. Pada konten "Pengen Siaran" dengan video yang berjudul "Himbauan untuk Adik-Adik yang Sedang Ospek" yang dibawakan oleh Tretan Muslim dan Choki Pardede dalam media sosial youtube yang disiarkan oleh channel Majelis Lucu pada bulan lalu mengangkat fakta budaya ospek di Indonesia dengan seleksi isu fenomena beredarnya video ospek yang memperlihatkan perilaku kasar secara verbal dari senior pada mahasiswa baru saat masa pengenalan kampus dan dunia perkuliahan secara daring dilaksanakan. Isu yang tidak dibahas atau dikeluarkan adalah kegiatan ospek yang dilakukan oleh universitas lain yang berjalan dengan baik dan diisi dengan webinar guna mengganti kegiatan offline seperti yang seharusnya. Penonjolan isu dibungkus secara komedi dengan isu senioritas dan perilaku kasar senior secara verbal saat kegiatan ospek berlangsung secara daring.

Kebebasan berekspresi secara komedi yang ditunjukan oleh Tretan Muslim dan Choki Pardede dengan memberikan opini atau kritik mengenai ospek di sosial media youtube. Opini atau kririk yang diberikan adalah kegiatan ospek tidak mendidik mahasiswa baru untuk memiliki mental yang kuat, kegiatan ini hanya menjadi ajang senioritas dan balas dendam dari senior pada mahasiswa baru. Hal ini menunjukan bahwa dengan pendekatan framing menurut Robert N. Entman, Tretan Muslim dan Choki Pardede memperbincangkan isu yang sedang beredar luas di khalayak dan membagikan opini atau kritik mereka mengenai isu yang sedang tersebar luas di khalayak. Kebebasan berekspresi mereka berdua secara humor sebagai bentuk kritik juga dibatasi dengan adanya sensor yang ditunjukan di video sebagai bentuk pembatasan kebebasan berekspresi supaya tidak banyak menyinggung banyak pihak. 


\section{DAFTAR PUSTAKA}

Anggoro, Ayub Dwi. 2014. Media, Politik, dan Kekuasaan (analisis framing model Robert N. Entman tentang pemberitaan hasil pemilihan Presiden, 9 juli 2014 di TV One dan Metro TV). Ponorogo: Fakultas Ilmu Sosial dan Ilmu Politik Universitas Muhammadiyah Ponorogo.

Basyaib, Hamid. 2006. Membela Kebebasan Percakapan tentang Demokrasi Liberal. Jakarta: Pustaka Alvabet dan Freedom Institute

Eriyanto. 2002. Analisis Framing: Kontruksi, ideology dan Politik Media. Yogyakarta: LKIS.

Hamad, Ibnu. 2004. Konstruksi Realitas Politik dalam Media Massa. Jakarta: Granit.

https://www.youtube.com/watch?v=Y64rMWBlqcs (diunduh pada tanggal 22 januari 2021 pukul 14:55 WIB)

Jimly Asshiddiqie, 2006, Kemerdekaan Berserikat, Pembubaran Partai Politik dan MK. Jakarta: Konstitusi Press.

Rahmanto, Tony Yuri. 2016. KEBEBASAN BEREKPSRESI DALAM PERSPEKTIF HAK ASASI MANUSIA: PERLINDUNGAN,PERMASALAHAN DAN IMPLEMENTASINYA DI PROVINSI JAWA BARAT. Jakarta selatan: badan penelitian dan pengembangan hukum dan HAM kementerian hukum dan HAM RI.

Sobur, Alex. 2006. Analisis Teks Media: Suatu Pengantar untuk Analisis Wacana, Analisis Semiotik, dan Analisis Framing. Bandung: PT Remaja Rosdakarya.

Sugiarto, V. D. (2016). Teknik humor dalam komedi yang dibintangi oleh stand up comedian. Jurnal E-Komunikasi, 4(1), 1-12

Suhadi. 1989. Humor Dalam Kehidupan. Jakarta: Gama Press.

Sujoko. 1982. Perilaku Manusia dalam Humor. Jakarta: Karya Pustaka.

UNESCO, Glosarium Toolkit Kebebasan Berekspresi bagi Aktivis Informasi tentang kebebasan berekspresi, hal.77

Wijana, I Dewa Putu. 2003. Dasar-Dasar Pragmatik. Yogyakarta: Penerbit Andi.

Maldo, M. (2017). Representasi Nilai Islam pada Iklan BNI Syariah" Hasanah Titik!"(Studi Analisis Semiotika Ferdinand De Saussure) (Doctoral dissertation, Universitas Islam Riau). 